\title{
A Narrative Analysis of Teacher Educators' Motivation: Evidence from the Universities of Sindh, Pakistan
}

\author{
Zafarullah Sahito \\ School of Applied Educational Science and Teacher Education, Philosophical Faculty, University of Eastern Finland, \\ Joensuu, Finland; \\ Sukkur IBA University, Airport Road, Sukkur, Sindh, Pakistan \\ Pertti Vaisanen \\ School of Applied Educational Science and Teacher Education, Philosophical Faculty, University of Eastern Finland, \\ Joensuu, Finland
}

\begin{abstract}
The study was conducted to explore the factors of motivation of teacher educators of the departments of Education at universities of Sindh province of Pakistan. The data was collected and analyzed through narrative analysis technique, the qualitative research design. The total sixteen factors of motivation were found as five intrinsic and eleven extrinsic respectively. The findings of the article would be suitable and reliable addition in to the available literature to understand the phenomenon of motivation in organizational setting to support their students' to work for the betterment of society.
\end{abstract}

Index Terms-motivation, narrative analysis, intrinsic, extrinsic

\section{INTRODUCTION}

Motivation word is a part of any popular organizational culture depending on physiological and psychological concepts to activate the behavior or a drive of individuals or process of moving to achieve the goal and incentive especially the inducement of a desired behavior (Han \& Yin 2016) with subordinates. It is an act of involvement and commitment with himself or herself to perform any assignment honestly and actively for the benefit of all stakeholders. It is a theoretical construct to explain the behavior of individual that provides the reason of any actions, desires and needs of a concern, based on the reality and truth directed by one's behavior, causes of the repetition of the behavior and vice versa (Elliot \& Covington 2001). Motivation is complexed term and considered as energy or drive to do something by nature that is differentiated through two aspects i.e. reasons for deciding to do something and sustain motivation that refers to the effort to do something. Dörnyei and Ushioda (2011) identified two dimensions of the definition of motivation to make researchers agree such as direction and magnitude of human behavior, as the teacher motivation (TM) is defined in terms of attraction, retention and concentration (Sinclair, 2008), which can be described as the motivation to teach and to remain in the profession (Dörnyei \& Ushioda, 2011).

The teacher motivation (TM) has been proved a crucial factor that closely related to student motivation, educational reform, teaching practice and teachers' psychological fulfillment and well-being (Han et al. 2016), depending on the interaction of both conscious and unconscious factors; needs and desires; incentives and rewards; value the organizational goals to achieve and the fulfill the expectations of the individuals and their peers. Research on TM developed and expanded quickly and vastly during late 1990s, which marked high increase in existing literature across various social and cultural contexts. Even though, some special issues were published on TM in 2008 focuses on the latest motivational theories, known as zeitgeist of interest means the spirit of the time or age (Watt \& Richardson, 2008). FIT-Choice model was based on the expectancy value theory to guide the systematic investigations to explore the factors influencing pre-service teachers' choice to teach (Watt et al. 2012). The first part of the model comprises a context, second intrinsic, personal and social utility values and third concerned with outcomes. The FIT-Choice model has a good explanatory ability and provides an integrated approach to study the diverse samples and settings (FokkensBruinsma \& Canrinus 2013; Watt et al. 2012) in different organizations.

\section{A. Purpose of Research}

The purpose of this study was to investigate the TEs perception about motivation and explore the specific motivational factors that enhance their job activities and engagement. As motivation is positively and strongly correlated with class choice, academic achievement (Legault et al. 2006), and student responsibility (Daniels \& Arapostathis, 2005).

\section{B. Research Questions}


Two research questions were made to find out the answers from the recorded narratives of TEs such as (a). What Intrinsic and extrinsic factors affect the motivation of TEs? (b). How TEs perceive and experience the process of motivation?

\section{LITERATURE REVIEW}

The literature review of the research study is consisting of two main areas such as intrinsic and extrinsic motivation. The details of both are as follows:

\section{A. Intrinsic Motivation}

Intrinsic motivation is a derive of actions from inside the person or from the activity itself, which positively affects the behavior, performance and well-being (Ryan \& Deci, 2000a) of employees. It increases the behavior of an employee to perform properly and actively for its own sake rather than to obtain material or social reinforcers. Intrinsic motivation is an expression and feeling of personal desires or values, which refers to do an activity for internal self-satisfaction (Lashway, 2001) based on the behavior of the employees towards their work. Intrinsic motivation can be encouraged through giving free hand to employees and appreciating their efforts and abilities (Ryan \& Deci, 2000b). Because, autonomy-supportive teachers catalyze their students to work through intrinsic motivation, curiosity and the desire for challenge, which create strong links between intrinsic motivation and satisfaction of the needs for autonomy, competence and relatedness (Ryan \& Deci, 2000a) as intrinsic motivation factors play a vital major role in TM in China primarily derived from intrinsic values of teaching. Whereas, the teacher attrition is identified in many European countries especially in Australia, England, New Zealand and USA (Dinham \& Scott, 2000; Watt \& Richardson, 2008), which is labeled as teacher demotivation and concerned with negative factors (Dörnyei \& Ushioda, 2011). As the negative influence may be related to particular events, experiences and factors related to any particular social environment, which demotivated the teachers who were once motivated in their past with their job but lost their interest due to some unforgettable reasons (Kiziltepe, 2008). Performance approach, goal orientation, graded performance trajectories; reflective thinking, intrinsic motivation and control-expectancy belief were associated with mastery goal orientation and achievement among Finnish and Swedish school teachers (Malmberg, 2008).

\section{B. Extrinsic Motivation}

Extrinsic motivation is the attainment of externally administered rewards such as salary, material possessions, prestige and positive evaluations, free accommodation, free meals, weekly duty, extra teaching allowances, advance payments in case of financial problems, leave of absence and free medical (Sansone \& Harackiewicz, 2000). The value of extrinsic motivation can be seen that money in the form of pay is the most obvious extrinsic reward, provides the means to achieve a number of different ends and outcomes. As the salaries of workers should be paid promptly and a corresponding increase in the salary should be increased to create and enhance the satisfaction and motivation among workers, which influence their performance directly. Because, pay has a strong positive affect on the employees' performance and is a powerful motivating tool (Bratton \& Gold, 2003). Whereas, extrinsic motivation is connected with the employee performance to achieve required results through some rewards and awards i.e. salary. Although the activity might be difficult, boring and unpleasant, but it can be made valuable and stimulating through rewards. Raise in workload increase the dissatisfaction and demotivation among teachers, while in private organizations the financial incentives are given to teachers for teaching their extra classes to increase their job satisfaction and motivation. As per application of Maslow's hierarchy of needs theory, employees dedicate their energy and time to their organizational duties and responsibilities if they are given sufficient payment to feed, shelter and protect their families well, which provide them an assurance of sustainability of above basics to pursue their organizational goals for further development.

\section{RESEARCH Methodology}

The qualitative research design was employed, revolving around epistemological and ontological assumptions of philosophy, supported by interpretivism and epistemological constructionism means the reality is multiple and multidimensional and the knowledge is constructed and a subjective in nature (Creswell, 2009) respectively. The data was collected through semi-structured interviews from the sample of TEs, who were approached through their heads of department and organizations. The short explanation of the research topic was made and shared with the recruited sample before interview. The list of characterizing traits was used as the criteria for judgement of the quality for reliability, validity and usability of the study (Sparkes \& Smith, 2014), which includes the topic richness; the significant contribution in literature; rich thoroughness and objectivity; selection of appropriate sample size and method; significant claims generated from the data; soundness and rationality; requirement and nature of topic (Tracy, 2010). Finally, the identical numbers as a code numbers were alloted to every TE to keep the interviewee identity and data confidential and secrete.

\section{A. Research Approach of the Study}

The narrative inquiry and analysis was extensively used for this study to collect and analyze the data, as narrative inquiry is suitable and strong tool to employ as an analysis tool. It has a capacity to records the correct and different 
human dimensions of experience and relationship concerned with cultural context (Clandinin \& Connelly, 2000), focuses on the details of stories with meaning depending on reality, inspired socially and culturally constructed knowledge and texture of experiences (Polkinghorne, 1995). It convert the said narratives in to the real meaning through analysis (Riessman, 2008), which constitutes the social reality of a narrator (Etherington, 2004), considered a powerful method to use for summative studies (Muylaert et al. 2014) with the criteria consisting of preparation, initialization, main narration, questioning and small talk conducted with one's own (Etherington, 2000) or with other's clients (Etherington, 2007).

\section{B. Participants of the Study}

Forty participants were recruited for the study through multiple perspectives such as the Snowball and convenience sampling techniques in order to collect the in-depth and real data. As, the number of research participants were ranging from 1 to 30 or 40, as to report their details properly (Creswell, 2012). The recruited sample of ( $\mathrm{n}=40)$ TEs was further divided as (19 male; 21 female), six professors (1 male; 5 female); one male associate professor, nineteen assistant professors ( 8 male; 11 female); and fourteen were lecturers ( 9 male; 5 female). The age group was stared from 28 to 58 years with an average mean of 44.65 .

\section{RESULTS AND DisCUSSIONS}

The results of this study show the sixteen factors, which have been explored from the collected data of the TEs about their motivation. All explored factors are settled down in table (1) with their description and definition in order to understand the phenomena well and comprehensively. These descriptions highlighted and provided the explanations of a researcher, which is prime work in qualitative research. Because qualitative researcher's position is looking like a bridge between the participants and readers, data collection and analysis and its sensible interpretations, which suits the areas from which the data collected, its culture, routines, rules and regulation. Qualitative researchers and its knowledge about any culture, system, phenomena, etc plays a vital role to explain the problems and their solutions properly and authentically for the betterment of the majority of the stakeholders.

The professional stories of sixteen TEs were found impressive to produce primary data for this study to analyze, as interviewees expressed their life experiences well supported by authentic reasons to quote as informative statements and narratives.

\section{A. Interesting Work}

The male TE (3), working as lecturer and having a more than seven years teaching experience, focused on interesting work and commented as "Interesting work increases my motivation and makes me energetic to perform my duties well. Especially when I get subjects as per my qualification and research areas to teach in different classes". The statement shows interesting work helps people a lot and make them cheer and joy on performing their task especially when they get the assignments matching with their research interest, qualification and experience. As the interesting work was found the pivotal factors, which significantly contributed in propelling employee motivation at their workplace (Hossain \& Hossain, 2012) concerned with their interests to increase the performance in order to get identification and respect in their particular organizations.

\section{B. Appreciation, Recognition and Achievement (Rewards \& Awards)}

The female TE (8), working as assistant professor and having a more than eleven years teaching and research experience, focused on appreciation, recognition and achievement as "My interest of work increased when I get appreciation on my work performance that makes me prominent among my colleagues and become my recognition in my institute and organization. It provides me the peace and rest of mind to work hard. The awards and rewards give me immense pleasure and increase my motivation to work more. To teach well with practical approaches and research based techniques". The narrative explained that how appreciation is created, maintained and enhanced. Interest of work was connected as a strong factor of appreciation on performance, which is the deepest desire in human nature, to be appreciated and valued (Ndungu, 2017) tends to have higher self-esteem, more confidence and willingness to take on new challenges and more eagerness to be innovative substantially. As performance of TEs became their identification and respect in the sight of their heads of departments and organizations, which create pleasure and encourage them as an employee and human being to achieve the highest in their life. 
TABLE. I.

FACTORS OF TEACHER MOTIVATION

\begin{tabular}{|c|c|}
\hline Factors or Themes & Description \\
\hline Interesting work. & Work that suits to the qualification, experience and willingness of the TE. \\
\hline Appreciation, recognition and achievement. & $\begin{array}{l}\text { Rewards and awards given to TEs based on their hard work and performance } \\
\text { transparently. }\end{array}$ \\
\hline Feeling involved in work progress. & $\begin{array}{l}\text { Responsibility, progress and product made by any TE when he or she was given any } \\
\text { involvement to work in any team. }\end{array}$ \\
\hline Job security. & Confident and security about job that will be long last. \\
\hline Financial and fringe benefits. & $\begin{array}{l}\text { Any financial and other benefits such as salary / good wages, medical, house and other all } \\
\text { allowances, etc. }\end{array}$ \\
\hline Teamwork (being a part of team). & Active participation to fulfil the responsibilities and duties with in any group of team. \\
\hline Help with personal problems. & Support acquired from colleagues and heads whenever face any personal problems. \\
\hline Trust building and management. & $\begin{array}{l}\text { Showing confidence and surety about any skills and capability of TEs that they will } \\
\text { complete the given work and assignment. }\end{array}$ \\
\hline $\begin{array}{l}\text { Mentoring, inspiration, commitment and } \\
\text { passion. }\end{array}$ & $\begin{array}{l}\text { The process of checking the activities by heads, which depends upon the leading and } \\
\text { guiding attitude to support them to be skilled and experienced. }\end{array}$ \\
\hline Status and respect. & $\begin{array}{l}\text { Any designation needs and acquire the respect during working hours as give and take } \\
\text { respect beyond any status and grade. }\end{array}$ \\
\hline Career advancement and job enrichment. & $\begin{array}{l}\text { Learning of new knowledge, skills and dispositions in order to become an expert to lead } \\
\text { the upcoming employees for future endeavours. }\end{array}$ \\
\hline $\begin{array}{l}\text { Employees' participation, support and } \\
\text { empowerment. }\end{array}$ & $\begin{array}{l}\text { Making surety that every employee has been given proper participation as per its } \\
\text { responsibility, duty, skills and expertise to empower himself or herself with support in } \\
\text { initial years of job. }\end{array}$ \\
\hline Home city posting. & $\begin{array}{l}\text { Posting in that city where the TEs families and relatives are living and they have sound } \\
\text { social relations. }\end{array}$ \\
\hline Transparent and tactful discipline. & $\begin{array}{l}\text { Same treatment or discipline as per rules and regulation for everyone in the organisation } \\
\text { to deal with the maters of the TEs. }\end{array}$ \\
\hline $\begin{array}{l}\text { Students' satisfaction and motivation, fair } \\
\text { dealing and mutual respect. }\end{array}$ & $\begin{array}{l}\text { Support students through keeping and maintaining the social relations and provide them } \\
\text { the good opportunities for learning and grooming inside and outside the class and } \\
\text { organisation. }\end{array}$ \\
\hline Good working conditions and environment. & $\begin{array}{l}\text { Making and availing all necessary facilities with proper system for work and performance } \\
\text { of duties with special reference to social and ethical support to each other. }\end{array}$ \\
\hline
\end{tabular}

\section{Feeling Involved in Work Progress (Responsibility, Progress and Product)}

The male TE (14), working as assistant professor and having a more than nine years teaching and research experience, focused on direct involvement in work and its progress as the key factor of motivation as "The given responsibility makes me motivated to fully involve in work all time. The active involvement gives me an insight of work and its progress, betterment and quality". The feeling involved in work progress consists on responsibility, progress and product, which enable the employee to progress well. This progress can be done by producing good products through a degree of freedom to make employees capable to take and implement their own decisions and ideas with liberty to take on the responsibility (Ruthankoon \& Ogunlana, 2003). As the responsible employees perform their job, based on their knowledge and try to learn new things to be done better, faster and cheaper.

\section{Job Security}

The female TE (18), working as professor and having a more than twenty years teaching and research experience, focused on job security as the key factor of motivation expressed as "Job security is like the heart in human body. The feeling of job security is like blood and oxygen to keep heart functional and active to live a healthy life. Job security is the only fundamental factor, which makes employees relax and motivated". Job security works as safeguard to protect human beings to increase the functioning through maintaining the healthy life and environment in different organizations especially at educational institutions. Pleasant work environment, friendly management, attractive salary package, organisational justice, career opportunities and job security (Okpara \& Wynn, 2008) were the topmost factors of job satisfaction and motivation. Because, job security make them strong to face different types of issues and problems through effective and positive impact to become a more productive human resource. On the other side, job insecurity creates an atmosphere of fear, worry and uncertainty that decreases the job performance as the lack of job security, organizational justice and satisfaction can be a cause of decrease in organisation productivity (Imran et al. 2015).

\section{E. Financial and Fringe Benefits (Salary / Good Wages, Medical, House and Other All Allowances)}

The male TE (4), working as lecturer and having a six years teaching experience, focused on financial and fringe benefits as the dominant key factor of motivation that minimizes and converts the issues and problems in to a happy life as "Market based salary or good wages minimize many problems in day-to-day life routines. Minimization of the problems, make TEs happy and motivated to fulfill their duties and responsibilities, which are visualized in overall progress and achievement of organizational goals to earn respect in society". The financial and fringe benefits i.e. salary or good wages, medical, house and other allowances support employees to fulfill the needs of their family members to live a happy life. As the prime goal of human resource management (HRM) strategies and reward management is to 
identify and satisfy the needs of employees through organizational reward system, which contains fringe benefits to make connection between motivations and rewards (Olsen, 2006). The motivated and high productive employees are to be paid through good wages according to their ability and performance otherwise the best employees can be stolen by your competitors in the markets.

\section{F. Teamwork (Being a Part of Team)}

The male TE (1), working as associate professor and having fourteen years of teaching and research experience, focused on team work such as "To be a part of any team, working on same project, training and activity make TEs motivated. Especially when they observe and experience mutual interest and help to other as one-team members. Mutual respect, consent, discussion and decision making make the project successful that strongly motivate the team members". Being a part of team, all members have to respect each other except any designation, grade and experience in all perspectives, which are important across multidisciplinary groups (Bruce \& Ricketts, 2008) to create collaboration. Because teams are built to learn from each other's expertise and experiences through supporting the phenomenon of team science, discipline structure, boundary work, challenges of interdisciplinary research, the direction of research and leadership in interdisciplinary teams (Adams et al. 2012) to bring positive change. The team members are attached emotionally with the goal and aim of the team, which make them social enough and bring them closure to each other in order to listen, respect and implement the instructions, objective-based team training, voluntarily formed teams, teambased leadership and communication system (Jiang, 2010). Listening carefully, respecting with heart and properly implementing the instruction is a guarantee of the success of whole team.

\section{G. Help with Personal Problems}

The female TE (20), working as assistant professor and having eight years of teaching and research experience, focused on help with personal problems as "TEs get motivation when their heads and colleagues help them in their personal problems. Especially when they need financial, physical, social and psychological help. To face any emergencies, illness, familial, and other societal". Receiving help from colleagues in the shape of financial, physical, social and psychological aspects to solve the personal problems is considered as the blessing as extrinsic motivators that help those who experience very low intrinsic motivation due to belief that they are unable to learn and work (Park, 2011). This blessing help TEs to face and solve the emergencies, illness, familial and societal problems, which reenergize and motivate them to back to their work with more social feelings about their coworkers and bosses. Employees' needs are to be known well by their heads through using different tactics to motivate each of them based on their personal wants and needs (Ganta, 2014). It can be vice versa, when the smart managers and heads do not help any of their colleagues to deal with the personal problems.

\section{H. Trust Building and Management}

The male TE (33), working as professor and having twenty-one years of teaching, training and research experience, focused on trust building and working relation management as "Trust building and development increase the level of motivation among TEs because trust increase their confidence level that appreciate them to work with high interest and responsibility, dedication, commitment, curiosity, trustworthy and honesty". Trust building and management were discussed and described as an important tool, which increase the confidence level of TEs, their colleagues, heads and students to develop positive exchange relationships (Bernerth \& Walker, 2009). Trust building increases the interest and responsibility among TEs, which create the dedication, commitment (Han et al. 2016), curiosity and trustworthy for their work to manage conflict and avoid trouble (Ertürk, 2010) in their department and organization. As, trust forms the foundation for effective communication, associate retention, motivation and contributions of discretionary energy. Five steps are important for creating and maintaining trust such as form teams to solve real work issues and processes; review projects and progress through meetings; build fun and shared experiences; do introduction as exercise to familiarize to all members of team; and celebrate group successes publicly.

\section{Mentoring, Inspiration, Commitment and Passion}

The female TE (23), working as assistant professor and having a more than eight years of teaching and research experience, focused on mentoring, inspiration, commitment and passion as "Heads and senior faculty members being mentors are the sources of inspiration for junior and newly appointed TEs. Inspiration motivates TEs to work out of the way to benefit their students to get success, commitment and passions for quality education". The heads, seniors and other colleagues help a lot as mentor and inspire their juniors to have commitment and passion towards their job, organization, colleagues and students for successful professional life, as passionate teachers are distinguished by their commitment (Han et al. 2015) to achieve their goals. The best leaders adopt, practice and coach for better performance through proper investment of time and energy (Carbonneau et al. 2008). They have an ability to sit down, mingled with their colleagues as team member and have an open and honest discussion about their issues and problems in order to increase the performance through their essential leadership skills concerned with emotional event requires receptiveness and awareness of social interdependence, which mentor to inspire others for achieving organisational goals and visions (Hudson, 2013). 
The male TE (11), working as assistant professor and having a more than twelve years of teaching and research experience, focused on status and respect as "Status counts a lot and respect is given to every TE at administrative offices in educational institutions and universities. Respect inspires, motivates and makes TEs to feel proud about their profession, as it is a prophetic profession to preach the humanity". Status describes the position or rank of a person in an organization, community and society based on the responsibilities fulfilled for the benefits of other members. Desire for status is a fundamental motive (Anderson et al. 2015). People respect a lot the person, who fulfilled his or her responsibilities to benefit the majority of the individuals in the society. Whereas, the rank of an employee especially the TE is directly linked with his or her authority, power, responsibility and other facilities to utilize it properly and authentically to benefit the people as they receive the respect and perceive to have higher status and power. Every TE wants and struggles for a higher status to be respected by the majority of the people as financial success, power and physical attractiveness and subjective well-being or self-esteem (Kahneman et al. 2006).

\section{K. Career Advancement and Job Enrichment}

The female TE (31), working as professor having more than nineteen years of teaching, training and research experience, focused on career advancement and job enrichment as "Attending various trainings and workshops, scholarships and study leave with all benefits and leniency motivate TEs. Trainings, workshops, research study in MS and $\mathrm{Ph} . \mathrm{D}$ are the core areas to advance the career through skill development to enrich the job". Career advancement and job enrichment found the high need and priority requirement of the employees of majority of the educational organizations, which attract, motivate and retain talented people to remain responsible in order to arrange, organize and design the work to produce finishing product (Robbins \& Judge, 2011). An authentic example of advancement is to enhance the employees' performance by increasing their satisfaction level through enhancement, enrichment and enlargement of job in their organization. The training and career development programs and organizational commitment have a partial effect on job satisfaction and motivation of employees, which facilitate a good ground and opportunity to get their promotion in their particular field and organization through getting help from their managers, heads and leaders by disclosing and announcing the avenues and positions for promotion. Whereas, the career advancement, job enrichment and job enlargement are the prime techniques of job design that increase the motivational level of employees (Sushil, 2014), which are essential for achieving work life balance and sustainability.

\section{Employees' Participation, Support and Empowerment}

The male TE (28), working as lecturer with more than seven years of teaching and training experience, focused on employees' participation, support and empowerment as “Giving and ensuring appropriate participation of TEs in policy designing, implementing and decision making process create trust between administration and faculty. Trust ensures the real participation of TEs and makes them empower to work well as an effective and beneficial employee. Empowerment can be ensured through giving appropriate participation to TEs at all matters and levels that ensures trust and motivation of TEs to work with free will'. In modern concept of HRM and industrial democracy, the employees' participation means the employees' empowerment. As the higher level of participation in decision making of employees are associated with significantly higher competence, meaning, impact and self-determination (Emamgholizadeh et al. 2011). This realization of ownership supports them throughout their stay with the organization to work with high interest. High interest and confidence make them empower to work with freedom to take decisions with in the required time for the better execution of the matters and issues. The confidence, trust, belief, commitment, dedication, trustworthy, motivation, satisfaction and innovativeness can be increased among employees through decision-making power and empowerment.

\section{Home City Posting}

The male TE (35), working as assistant professor with more than ten years of teaching, training and research experience, focused on home city posting as "I am working in the university situated in my home city, where I am living and settle down since many years. Due to posting in home city, I look after my children and parents very well. The life in this city goes on excellently as per previous routines such as to go for sports, meet relatives and friends regularly. The social life and work go parallel and smooth, which highly motivate me to work well". Home city posting provides the opportunity to the TEs to fulfill their duties and responsibilities regarding their parents, brothers, sisters, friends, relatives and other members of society on social and humanitarian basis. Posting and housing play a pivotal role as a motivating factor to improve the performance of teachers through saving their time and fatigue (Okino, 2008). As a practice of assigning posts and transfers in many countries, do weaken the system's functioning and the core social values of the institutions (Schaaf \& Freedman, 2015). The quite frequent transfers are done in the public sector in Balochistan, Pakistan, which affect negatively (Collins et al. 2000) on the personal and family life of employees, administration and the system especially the ongoing projects. As mentioned by different authors in their studies about medical projects that frequent transfers hindered the particular health project (Barker et al. 2007). Living at one place especially at home town became a great opportunity for them to play different games with their old friends on regular basis and make new friends during their engagements with sports and recreational activities, which make them fresh and strong to work well.

\section{N. Transparent and Tactful Discipline}


The female TE (37), working as lecturer with more than eight years of teaching and training experience, focused on transparency and tactful discipline as "Transparency in dealing with matters and assignments increase the justice, equity and equality system in an organization, which make TEs satisfy and happy to accept responsibility of their work. Feeling responsibility of work create discipline among them to complete their assignments within given time. The routine practice of fulfillment of responsibilities creates the techniques of discipline among TEs and increase their sense of duty". Transparency and tactful discipline is a process, which attract the majority of employees to work without having any fear about injustice, unethical manners, illegal support, inequality and inequity. As, transparency considers a fundamental driver of efficiency to value in any organization (Berggren \& Bernshteyn, 2007), which enables the workers to achieve the goals to promote successful execution of the transparency strategy (Kaplan \& Norton, 2006), but tactful discipline was kept on last choice explored by the studies of Kovach (1995) and Pia DiPaola (2010). Whereas, tactful discipline was found less important in the professional life of teachers but highly important in the practice of management.

\section{O. Students' Satisfaction and Motivation, Fair Dealing and Mutual Respect}

The male TE (30), working as lecturer with more than eleven years of teaching and training experience, focused on the students' satisfaction and motivation, fair dealing and mutual respect as "The quality of teaching-learning process, availability of resources and the dealing of TEs make students satisfy and motivated. Fair and transparent dealing of TEs with all students motivate the both stakeholders to have good working relations that create mutual understanding to motivate and respect each other for interactive and supportive learning environment". Students' satisfaction and motivation is directly interrelated, intermingled and interacting with the TM, connected and concerned with collective benefits and target awareness, which has an interfering effect on job motivation. Chinese culture prioritizes the collective or group benefits, and organizational roles or missions are viewed as greater than personal needs as the students' satisfaction was found connected directly with TM, which has a rich and diverse history of fair dealing and mutual respect. Because, motivations drive individuals' behavior (Porter et al. 2003), which is not a static psychological construct, but a dynamic process to be a successful member of the organization and society. Students discuss their matters with their teachers in order to get suitable suggestion about their issues and problems. Students' do teacher evaluation and highlight their pedagogy, andragogy, management and organization of their courses, facilitation, support, fair dealing and mutual respect to their students.

\section{P. Good Working Conditions and Environment}

The female TE (32), working as professor with more than twenty-three years of teaching, training and research experience, focused on good working conditions and environment as "Good working conditions and environment provide most of the material resources and peace of mind to work well with intellectual colleagues to learn from them. The instructions, suggestions and freedom able them to discuss and make effective decisions". Good working conditions and environment provides a good material and human resources to faculty members, which help them a lot to complete their assignments well in time. As the study of Jayaweera (2015) explored the importance of working conditions that has a strong positive effect on work motivation, which appreciate the employees to improve their performance. The main resources of good working environment and conditions are comprise of availability of human resources and their support, all time availability of electricity, computers, printers, offices, multimedia and high-speed internet facility that support the TM and their performance (Vischer, 2008), success and achievement. Whereas, the environment comprises of both physical and psychosocial components to increase performance with incentives at workplace because they have positive impact on employee's motivation and performance. Furthermore, a safe, clean and well-managed sanitary building also help the employees to take pride in their workspace that can be an office, cubicle or workstation, which feel and like them that they have a place belongs solely to them.

The explored factors are divided and settle down as intrinsic and extrinsic factors of motivation. Where intrinsic factors comprise of five explored factors such as interesting work; appreciation, recognition and achievement (rewards $\&$ awards); feeling involved in work progress (responsibility, progress and product); employees participation, support and empowerment; and students satisfaction and motivation, fair dealing and mutual respect. While, extrinsic factors comprise of eleven explored factors such as job security; financial and fringe benefits (salary / good wages, medical, house and other all allowances); team work (being a part of team); help with personal problems; trust building and management; mentoring, inspiration, commitment and passion; status and respect; career advancement and job enrichment; home city posting; transparent and tactful discipline; good working conditions and environment. The majority of the explored factors support the finding and the theories of Maslow's Hierarchy of Needs Theory, Alderfer's Modified Need Hierarchy Theory, Herzberg's Two Factor Theory and McClelland's Achievement Motivation Theory. Because, the conditions of employees and the systems of educational organizations in developing countries just support and struggle for the basic needs and requirement of human beings. Even though in $21^{\text {st }}$ century, the employees are still searching and working hard to get a good job and salary for the survival of their families. There is a great need to create the social welfare system in order to eradicate the unemployment and the fears of snatching of job of employees especially teachers like developed countries to focus and work sincerely without any fears for the betterment of the society. Because the performance of every teacher or TE or employee is important and necessary for any organization to progress that can be achieved through employee motivate, their positive attitude and reinforcement 
(Sahito \& Vaisanen, 2018).

The findings of the study conducted on TEs by Sahito \& Vaisanen (2018) are highly concerned, reliable and sound in this regards. Because, the conducted study is counted among important research conducted on the TEs, whose results were found authentic and reliable. It is an excellent addition in to the available literature of motivation to understand the available phenomenon of teacher motivation, its needs and requirements, its process and causations to make teachers relax through maintaining the working environment and social relationships safe. Their findings consists of the perception and experience of TEs that have been dealt with in their organizations such as motivation as: respect and personal initiative; the discipline in life; need fulfilment; self-realization and self-satisfaction; model consideration and inspiration; social services; job security; readiness; work and time management; dedication, commitment, delivery and performance; students' satisfaction and their support; social relationship and interaction; responsibilities and duties; professional growth and development; cognitive competence, scholarship and authority; and self-assessment and selfevaluation (Sahito \& Vaisanen, 2018). These results show the great importance of the findings of motivation study in the life of TEs.

\section{CONCLUSION}

Based on the findings of the study we conclude that the extrinsic factors of motivation played vital role to motivate the TEs. Because, extrinsic motivation factors provide a suitable platform and the high way to the intrinsic factors of motivation. Without the will, permissions and notifications of the heads of the organization no TE would be able to do any effective input for the betterment of any organization and its all stakeholders. Without visionary leadership, nothing would be done at any level to motivate the employees of any organization because it is the greatest job of visionary and active leadership who work hard to know the professional, psychological, social and physical needs of the employee for better-required results. As the material resources, policies and planning, instructions and guidelines are to be developed by the will of the heads of the organization. The extrinsic factors have a more power and energy to infuse and create the interest among the employees to get work done for quality education in a proper and authentic way to progress well at national and international level through the improvement of the standards of education especially in Pakistan (GOP, 2009).

The results can be generalized, as each employee's performance is important for the progress of an organization, which motivate the employees through positive attitude and reinforcement to strengthen their behavior based on consequences (Wei \& Yazdanifard, 2014) in the organization. As Hinkin and Schriesheim (2004) explore that employees who received their feedback may be positive, negative or corrective showed improved performance in their daily routines. Because, employees do their work well when the high level of motivation is available for them (Fagbohungbe \& Longe, 2011) as rewards and punishment (Kohn, 2004), appreciation and sense of belonging to achieve the required goals of the organization. While, no or less appreciation on good performance diminished employees' effectiveness and reduced their satisfaction (Hinkin \& Schrieshem, 2004) and motivation. Therefore, it can be said that both the extrinsic and intrinsic factors of motivation are important to create the interest among TEs to work well for the betterment of their organization and concerned stakeholders such as students and faculty.

\section{FUTURE DIRECTIONS}

The findings of the study could be researched further through quantitative methods for more understanding of the phenomenon of motivation of TEs.

\section{REFERENCES}

[1] Adams, B. L. M.S., Cain, H. R., Giraud, V., \& Stedman, N. L. P. (2012). Leadership, motivation, and teamwork behaviors of Principal investigator's in interdisciplinary teams: A Synthesis of research. Journal of Leadership Education, 11(2), $171-191$.

[2] Anderson, C., Hildreth, J. A. D., \& Howland, L. (2015). Is the Desire for status a fundamental human motive? A Review of the empirical literature. Psychological Bulletin, 141(3), 1-28.

[3] Barker, C., Bird, C. E., Pradhan, A., \& Shakya, G. (2007). Support to the safe motherhood programme in Nepal: an integrated approach. Reproductive Health Matters, 15(30), 81-90.

[4] Berggren, E., \& Bernshteyn, R. (2007). Organizational transparency drives company performance. Journal of Management Development, 26(5), 411-417.

[5] Bernerth, J. B., \& Walker, H. (2009). Propensity to trust and the impact on social exchange: An Empirical investigation. Journal of Leadership and Organizational Studies, 15 (3), 217-226.

[6] Bratton, J., \& Gold, J. (2003). Human resource management: Theory and Practice, 3rd (ed.). Palgrave Macmillan, New York.

[7] Bruce, J. A., \& Ricketts, K. G. (2008). Where's all the teamwork gone? A qualitative analysis of cooperation between members of two interdisciplinary teams. Journal of Leadership Education, 7(1), 65-75.

[8] Carbonneau, N., Vallerand R. J., Fernet, C., \& Guay, F. (2008). The Role of passion for teaching in intrapersonal and interpersonal outcomes. Journal of Educational Psychology, 100(4), 977-987.

[9] Clandinin, D. J., \& Connelly, F.M. (2000). Narrative Inquiry: Experience and story in qualitative research. Published by Jossey-Boss, John Wiley \& Sons, Inc., San Francisco.

[10] Collins, C. D., Omar, M., \& Hurst, K. (2000). Staff transfer and management in the government health sector in Baluchistan, Pakistan: problems and context. Public Administration and Development, 20, 207- 220. 
[11] Creswell, J. W. (2012). Educational research: planning, conducting, and evaluating quantitative and qualitative research, 4th (ed.). Pearson Education, Inc., Boston, USA.

[12] Creswell, J. W. (2009). Research design: Qualitative, quantitative and mixed methods approaches, 3rd (ed.). London, England: Sage Publications.

[13] Daniels, E., \& Arapostathis, M. (2005). What do they really want? Student voices and motivation research. Urban Education, 40(1), 34-59.

[14] Dinham, S., \& Scott, C. (2000). Moving into the third, outer domain of teacher satisfaction. Journal of Educational Administration, 38, 379-396.

[15] Dörnyei, Z., \& Ushioda, E. (2011). Teaching and researching motivation, 2nd (ed.). New York, NY: Longman.

[16] Elliot, A. J., \& Covington, M. V. (2001). Approach and avoidance motivation. Educational Psychology Review, 13(2), 73-92.

[17] Emamgholizadeh, S., Matin, H. Z., \& Razavi, H. Z. (2011). Is participation in decision making related to employee's empowerment? African Journal of Business Management, 5(9), 3504-3510.

[18] Ertürk, A. (2010). Exploring predictors of organizational identification: Moderating role of trust on the associations between empowerment, organizational support, and identification. European Journal of Work and Organizational Psychology, 19 (4), 409-441.

[19] Etherington, K. (2000). Narrative approaches to working with adult male survivors of childhood sexual abuse. London: Jessica Kingsley.

[20] Etherington, K. (2004). Becoming a reflexive researcher: using ourselves in research. London: Jessica Kingsley.

[21] Etherington, K. (2007). Ethical research in reflexive relationships. Qualitative Inquiry, 13 (50), 599-616.

[22] Fagbohungbe, B. O. \& Longe, S. O. (2011). An introductory psychology: Concepts and principles. Lagos: Kotleb consults.

[23] Fokkens-Bruinsma, M., \& Canrinus, E. T. (2013). Motivation for becoming a teacher and engagement with the profession: Evidence from different contexts. International Journal of Educational Research, 65, 65-74.

[24] Ganta, V. C. (2014). Motivation in the workplace to improve the employee performance. International Journal of Engineering Technology, Management and Applied Sciences, 2(6), 221-230.

[25] Government of Pakistan [GOP], (2009). National professional standards for teachers in Pakistan. Policy and Planning Wing, Ministry of Education, Islamabad.

[26] Han, J., Yin, H., \& Wang, W. (2015). Exploring the relationship between goal orientations for teaching of tertiary teachers and their teaching approaches in china. Asia Pacific Education Review, 16, 1-11.

[27] Han, J., \& Yin, H. (2016). Teacher motivation: Definition, research development and implications for teachers. Cogent Education, 3(1), 1-18.

[28] Han, J., Yin, H., \& Wang, W. (2016). The effect of tertiary teachers' goal orientations for teaching on their commitment: the mediating role of teacher engagement. Educational Psychology, 36, 526-547.

[29] Hinkin, T.R. \& Schrieshem, C.A. (2004). If you don't hear from me, you know you are doing fine: The effect of management non-response to employee performance. Cornell Hotel and Restaurant Administration Quarterly, 45 (4) 362-372.

[30] Hossain, M. K., \& Hossain, A. (2012). Factors affecting employee's motivation in fast food industry: The Case of KFC UK LTD. Research Journals of Economics, Business and ITC, 5, 22-29.

[31] Hudson, P. (2013). What Makes School Leaders Inspirational and How Does This Relate to Mentoring? Open Journal of Leadership, 2(4), 87-94.

[32] Imran, R., Majeed, M., \& Ayub, A. (2015). Impact of organisational justice, job security and job satisfaction on organisational productivity. Journal of Economics, Business and Management, 3(9), 840-845.

[33] Jayaweera, T. (2015). Impact of Work Environmental Factors on Job Performance, Mediating Role of Work Motivation: A Study of Hotel Sector in England. International Journal of Business and Management, 10(3), 271-278.

[34] Jiang, X. (2010). How to motivate people working in teams. International Journal of Business and Management, 5(10), 223229.

[35] Kahneman, D., Krueger, A. B., Schkade, D., Schwarz, N., \& Stone, A. A. (2006). Would you be happier if you were richer? A focusing illusion. Science, 312, 1908-1910.

[36] Kaplan, R. \& Norton, D. (2006). Alignment, Harvard Business School Press, Boston, MA.

[37] Kiziltepe, Z. (2008). Motivation and demotivation of university teachers. Teachers and Teaching, 14, 515-530.

[38] Kohn, A. (2004). What does it mean to be well educated? Boston: Beacon press.

[39] Kovach, K.A. (1995). Employee motivation: Addressing a crucial factor in your organization's performance. Employment Relations Today, 93-107.

[40] Legault, L., Green-Demers, I., \& Pelletier, L. (2006). Why do high school students lack motivation in the classroom? Toward an understanding of academic motivation and the role of social support. Journal of Educational Psychology, 98, 567-582.

[41] Malmberg, L. E. (2008). Student teachers' achievement goal orientations during teacher studies: Antecedents, correlates and outcomes. Learning and Instruction, 18, 438-452.

[42] Muylaert, C.J., Junior, V.S., Gallo, P.R., Neto, M.L.R., \& Reis, A.O.A. (2014). Narrative interviews: An Important resource in qualitative research. Rev Esc Enferm USP, 48(2), 184-189.

[43] Ndungu, D. N. (2017). The Effects of rewards and recognition on employee performance in public educational institutions: A Case of Kenyatta University, Kenya. Global Journal of Management and Business Research: A Administration and Management, 17(1), 42-68.

[44] Okino, P. (2008, April 7th). Housing teachers' important. Monday, New Vision. P.8.

[45] Okpara, J. O., \& Wynn, P. (2008). The Impact of ethical climate on job satisfaction, and commitment in Nigeria: Implications for management development. Journal of Management Development, 27(9), 935-950.

[46] Olsen, H. D. (2006). Wages, fringe benefits and worker turnover. Labour Economics, 13(1), 87-105.

[47] Park, Y. (2011). How motivational constructs interact to predict elementary students' reading performance: Examples from attitudes and self-concept in reading. Learning and Individual Differences, 21(4), 347-358. 
[48] Pia DiPaola, C. (2010). Employee motivation factors: A Reexamination of Kovach's study 10 years later, Business Masters. http://fisherpub.sjfc.edu/business_etd_masters/1.

[49] Polkinghorne, D. E. (1995). Narrative configuration in qualitative analysis. Qualitative studies in education, 8(2), 5-22.

[50] Porter, L. W., Bigley, G. A., \& Steers, R. M. (2003). Motivation and work behavior, 7th (ed.). New York: McGraw-Hill.

[51] Riessman, C. K. (2008). Narrative methods for the human sciences. London: Sage.

[52] Robbins, S. P., \& Judge, T. A. (2011). Organisational behavior, 14th (ed.). Upper Saddle River, NJ: Prentice Hall.

[53] Ruthankoon, R., \& Ogunlana, S. O. (2003). Testing Herzberg's Two-Factor Theory in the Thai construction industry. Engineering, Construction and Architectural Management, 10(5), 333-341.

[54] Ryan, R. M., \& Deci, E. L. (2000a). Self-determination theory and the facilitation of intrinsic motivation, social development, and well-being. American psychologist, 55(1), 68-78.

[55] Ryan, R. M., \& Deci, E. L. (2000b). Intrinsic and extrinsic motivations: Classic definitions and new directions. Contemporary Educational Psychology, 25, 54-67.

[56] Sahito, Z., \& Vaisanen, P. (2018). Perception and Experience of Teacher Educators about Their Motivation: A Case Study Approach. Journal of Language Teaching and Research, 9(3), 480-490. DOI: http://dx.doi.org/10.17507/jltr.0903.05

[57] Sansone, C., \& Harackiewicz, J. (2000). Intrinsic and extrinsic motivation, 1st (ed.). Academic Press, San Diego, CA.

[58] Schaaf, M., \& Freedman, L. P. (2015). Unmasking the open secret of posting and transfer practices in the health sector. Health Policy and Planning, 30, 121-130.

[59] Sinclair, C. (2008). Initial and changing student teacher motivation and commitment to teaching. Asia-Pacific Journal of Teacher Education, 36, 79-104.

[60] Sparkes, A. C., \& Smith, B. (2014). Qualitative research methods in sport, exercise and health from process to product. Oxford, England: Routledge.

[61] Sushil, S. (2014). Role of job enrichment and job enlargement in work life balance. Global Journal of Finance and Management, 6(3), 239-244.

[62] Tracy, S. J. (2010). Qualitative quality: Eight big-tent, criteria for excellent qualitative research. Qualitative Inquiry, 16(10), 837-851.

[63] Vischer, J. C. (2008). Towards an environmental psychology of workspace: How people are affected by environments for work. Architectural Science Review, 51(2), 97-108.

[64] Watt, H. M. G., \& Richardson, P. W. (2008). Motivation for teaching. Learning and Instruction, 18, $405-407$.

[65] Watt, H. M. G., Richardson, P. W., Klusmann, U., Kunter, M., Beyer, B., Trautwein, U., \& Baumert, J. (2012). Motivations for choosing teaching as a career: An international comparison using the FIT-Choice scale. Teaching and Teacher Education, 28, 791-805.

[66] Wei, L. T. \& Yazdanifard, R. (2014). The impact of Positive Reinforcement on Employees' Performance in Organizations. American Journal of Industrial and Business Management, 4, 9-12.

Zafarullah Sahito is Ph.D. in Educational Science and Teacher Education and a Post-doc researcher at the School of Applied Educational Science and Teacher Education, Philosophical Faculty, University of Eastern Finland, Joensuu. Dr. Sahito is a permanent employee (Assistant Professor) at the Department of Education, Sukkur IBA University, Sindh, Pakistan. He has over 20 years of teaching, training and research experience at school and university level in Pakistan.

Pertti Vaisanen is working as a Professor and vice Dean at School of Applied Educational Science and Teacher Education, Philosophical Faculty, University of Eastern Finland, Joensuu. Dr. Vaisanen has over 35 years of teaching, training, administrative and research experience in Finland. He supervises many Masters, doctoral and post-doc researchers at his school in Joensuu. 